\title{
Corporate Social Responsibility: To What Extent Businesses Should Contribute From Theoretical Perspective?
}

\author{
Faieza Chowdhury \\ Southeast Business School, Southeast University, Banani, Dhaka 1213, Bangladesh.

\section{Abstract} \\ Today there is a general consensus among academics, practitioners and policy makers that businesses should use \\ their resources and power to minimize problems in the society. However, there is still some disagreements \\ regarding to what extent a business should get involve in social matters. Some people want businesses to assume \\ significant responsibilities in order to alleviate various social problems, while others claim that businesses should \\ only invest in social activities if they give positive returns. There is a great amount of rhetoric in this subject and \\ many researchers have examined the reasons both for and against the concept of CSR, pointing out that \\ corporations receive a social sanction from the society that requires them to contribute towards growth and \\ development of the society. Nevertheless, critics of CSR point out that companies are already contributing to \\ society by delivering goods and services, creating employment, paying taxes to government and providing returns \\ to shareholders. In this article we provide a comprehensive review of the various concepts of corporate social \\ responsibility. We also examine the arguments and philosophies for engaging in social activities.
}

Keywords: Corporate social responsibility, Shareholder theory, Stakeholder theory

DOI: $10.7176 / \mathrm{EJBM} / 11-12-04$

Publication date: April $30^{\text {th }} 2019$

\section{Introduction}

Over the years many different arguments were raised regarding the concept of corporate social responsibility. Different scholars across the globe expressed the concept of CSR in various ways. To some it conveys the idea of legal responsibility or liability while to others it means social responsible behavior in an ethical sense. According to Keith and Blomstrom (1971), CSR refers to firm's consideration of and response to issues which are beyond the narrow economic, technical and legal obligations of the firm. Bowen (1953) set forth an initial definition of social responsibility. He states that CSR refers to the obligations of businessmen to pursue those policies, decisions or to follow lines of action which are desirable in terms of objectives and value of society. Davis (1960) provided his definition of corporate responsibility and referred to it as the businessmen's decisions and actions taken for reasons at least partially beyond the firm's direct economic or technical interest. According to McGuire (1963), "the idea of social responsibility supposes that the corporation has not only economic and legal obligations but also certain responsibilities to society which extend beyond these obligations". Walton (1967) defines corporate social responsibility as it recognizes the intimacy of relationships between the corporation and the society and realizes that such relationships must be kept in mind by the top managers as the corporation and the related groups pursue their respective goals. According to Friedman (1970), "there is one and only one responsibility of businesses - to use its resources and engage in activities designed to increase its profits so long as it stays within the rules of the game, which is to say, engages in open and free competitions, without deceptions and fraud". According to Heald (1970), corporate social responsibility deal with subjects such as "philanthropy, employee improvements in working conditions, industrial relations and personnel policies, customer relations and shareholder relations". Johnson (1971) suggests that "a socially responsible firm is one whose managerial staff balances a multiplicity of interests. Instead of striving only for larger profits for its stockholders, a responsible enterprise also takes account of its employees, suppliers, dealers, local communities and the nation." A major debate over the actual meaning of CSR took place in 1972. Manne and Wallich (1972) set forth their definition of CSR where they have stated that a proper definition of CSR must include certain elements: to qualify as socially responsible corporate action, a business expenditure or activity must be one for which the marginal returns to the corporation are less than the returns available from some alternative expenditure, must be purely voluntary, and must be an actual corporate expenditure rather than a conduit for individual largesse". Sethi (1975), point out that social responsibility refers to going beyond the concept of social obligation which is economic and legal only.

Although the term CSR can be defined in a multitude of ways, the most frequent used definition of CSR comes from Archie Carroll in 1979. He states that the social responsibility of businesses encompasses the economic, legal, ethical and discretionary expectation that society has of organizations at a given point in time. Although in the past the concept of CSR has been questioned and rejected by many business leaders but today CSR has become the central focus of a modern corporation. An influential contributor of social responsibility Frederick (2006) states that "social responsibility mean that corporations should oversee the operations of an economic system that fulfills the expectations of the public". According to Lee (2008), corporate social responsibility has been transformed from an irrelevant and frowned upon idea to one of the most widely accepted concepts in the business world. Furthermore, Basu and Palazzo (2008) point out that today the concept of CSR has 
shifted from the question of "why" to "what" and "how" firms need to contribute towards the society.

\section{Why should a business engage in CSR?}

There are various arguments both for and against business conducting corporate social responsibilities. Some economist such as Friedman (1971) argue that "there is one and only one social responsibility of business - to use its resources and engage in activities designed to increase profits so long as it stays within the rules of the game, which is to say, engage in open and free competition without deception or fraud". However, other economists such as Samuelson (1971) states that "a large corporation these days not only may engage in social responsibility, it had damn well better try to do so". Which view of social responsibility is more realistic and viable for today's society is still debatable? In this paper we examine the arguments offered both for and against businesses engaging in corporate social responsibilities.

\subsection{Arguments for Corporate Social Responsibility}

2.1.1 Achieve greater rewards: One main reason why firms should assume social responsibilities is the fact that such activities can contribute to higher profits in the future. In general the society expects a business to act in ways which will not just benefit itself but bring benefits to the community at large. Hence a better society will produce a better environment for business in the form of higher quality labor, lower cost of production, greater property protection due to reduction in crimes etc. Therefore, as businesses spend more money on social programs this will eventually yield more benefits for them in the long run.

2.1.2 Enhance public image: The idea of public image refers to benefits for individual firms as they maintain a good image in the society. Society gave business its charter to exist and this charter can be amended and revoked at any time if the business fails to live up to society's expectations. Hence if a business wants to retain its role and power, it must meet the society's needs. Moreover, any business which involves in fulfilling the aspirations of the society creates better image in the public. Such companies can gain by attracting loyal customers and employees who feel proud to be a part of the company.

2.1.3 Increase stockholders' return: According to Wallich and McGowan (1970), businesses which engage in certain kind of social activities can bring greater returns to their shareholders. They used sophisticated analytical procedures to show types of social responsive behavior which brings return to corporate sector as a whole and can actually operate to the benefit of the holder of a diversified portfolio. Hence a firm's failure to be socially responsible can deprive shareholders of greater returns from their investment.

2.1.4 Minimize government intervention: The main goal of any government is to ensure equilibrium in the society. To achieve this goal, all parties of the society must meet their social requirements. To prevent anti-social activities, government can influence organizations by passing regulations to protect environment, ensure work place safety, maintain equal opportunity etc. In order to prevent excessive government intervention, it is better for the firms to assume social responsibilities on their own.

2.1.5 Moral obligation: society is a system and a business is one of its sub-system. All sub-systems of society should operate for the betterment of the whole system and not only for its own betterment. Hence on this ground, businesses have moral obligations to give something back to the society. Therefore, businesses are responsible for the society as a whole and profit motivation should not have precedence over other motives of the society.

\subsection{Arguments against Corporate Social Responsibility}

2.2.1 Focus should be on profit maximization: There are some economists who point out that manager are the agents of the stockholders hence all their decisions should be driven by the desire to maximize shareholder's profits. Milton Friedman, a major proponent of this view, point out that if managers or executives use resources for social responsibility then in a way they are imposing taxes on others. In his book "Capitalism and Freedom" Friedman (2002) states that "in a free enterprise private property system, a corporate executive is an employee of the owners of the business. He has direct responsibility to his employers and that responsibility is to conduct the business in accordance with their desires, which generally will be to make as much money as possible while conforming to the basic rules of society, both those embodied in law and those embodied in ethical custom".

2.2.2 High cost of social activities: Some economists argue that businesses have all the valuable resources which can be applied to solve various social problems. Nevertheless, businesses must utilize their resources wisely because these resources can easily dwindle away. If businesses use their resources for social activities then they will have to bear additional costs. This increase in costs can lead to a decrease in profits which can eventually force some weak firms out of the business.

2.2.3 Unqualified to engage in social work: Most businesses may lack the perceptions and skills to perform social work. According to Keith (1973), the objective of most companies is to maximize profits hence they just do not feel at home engaging in social matters. Moreover, some critics of CSR argue that businesses lack the qualifications to solve social problems. Some extreme opponents of CSR further point out that most of the businessmen are very single-minded and only engage in the pursuit of higher profits. Hence these people should 
not be trusted with social duties which primarily require concern for others as most businessmen are philosophically and emotionally unfit for this kind of job.

2.2.4 Loss of competitive advantage in the market: Proponents of CSR often assume that businesses have unlimited ability to conduct in social activities. However, the reality is quite different as businesses also have some limitations. If a business engages in social issues then it will increase its cost of production and operation. This will eventually be reflected in terms of higher prices of their products in the international markets thus such companies will find it difficult to compete with other firms resulting to a decrease in market share.

2.2.5 Excessive power to corporations: Some critics of CSR point out that corporations are one of the most powerful institutions in the society today. The process of combining social activities with business activities would give businesses excessive power which they can misuse. Moreover, businesses have no line of accountability to the people hence the social needs of people should not be met by the helping hands of the business.

\section{Shareholder Theory v/s Stakeholder Theory}

The two sides of the debate concerning CSR can be expended in terms of two distinctive theories namely the stakeholder theory and the shareholder theory. The advocates of the shareholder theory states that business should only obey the required laws and only focus on maximizing shareholder wealth. Nevertheless, proponents of stakeholder theory point out that in addition to complying with laws, a firm should take steps to alleviate the various social problems.

\subsection{Stakeholder Theory}

This theory states that corporations should consider the impact of their actions upon suppliers, customers, general public and other various stakeholders (Jensen, 2002; Freeman, Wicks, \& Parmar, 2004; Lee, 2008). Proponents of stakeholder theory believe that corporations should meet society's discretionary expectations. Supporters of this view claim that the society should allow businesses to solve social problems as other institutions have failed to do so (Davis, 1973). Legitimacy theory which is an extreme version of the stakeholder theory, argues that companies have implicit contracts with stakeholders to provide for their long term needs and wants. By meeting the needs of the stakeholders a company legitimates its existence (Guthrie \& Parker, 1989).

However, there are some arguments which are voiced against the stakeholder theory which are listed below:

- The stakeholder theory contradicts the ideas proposed by the corporate governance. In stakeholder theory the focus of a corporation changes from meeting shareholder's needs to stakeholder's needs. Hence if firms direct their goals to benefit stakeholders by implementing unprofitable CSR programs then they are not acting in the best interest of the shareholders.

- Another argument against stakeholder theory is that CSR can lead to more rigorous environment and social regulation for companies which can increase their cost and put them in a competitive disadvantage with reduction in profits.

- Another problem of the stakeholder theory is the presence of competitive interest. If a business attempts to meet the needs of its customers then employees or other stakeholders ' needs may have to be compromised which can lead to disgruntlement.

\subsection{Shareholder Theory}

On the other side of the debate we have the shareholder theory which states that the main objective of a firm is to maximize wealth of shareholders (Jensen, 2002; Smith, 2003). Supporters of this theory argue that CEOs are not hired by the shareholders to act as government or charity organizations. They were hired mainly to make money for the shareholders. Two historical figures, Adam Smith and Milton Friedman supported the concept of shareholder wealth maximization. They point out that no matter how noble the cause is but shareholder's money should not be utilized in an unprofitable manner. Smith (1981) argued that as firms pursue their own interest of maximizing shareholders wealth, it can ultimately promote social welfare through the invisible hand. Friedman (1970) a proponent of shareholder theory also emphasized on shareholders wealth maximization. He states that unless there is a clear mandate from company's owners, philanthropic activities should not be funded by the firms. Some scholars as Freeman and Liedtka (1991) argued that CSR should be fully abandoned as it is not practical. According to these scholars, firms do not have the necessary expertise to alleviate social problems.

Nevertheless, the shareholder theory is not without its shortcomings. Some arguments which are voiced against this theory as listed below:

- Sometimes activities conducted by businesses can result in negative externalities to the community. For instance, a business may locate its new plant in a certain location due to high profitability. But this decision can have a negative impact on the people living in that location if the business emits vast amount of pollutants that could seriously harm the people.

- Another argument against the shareholder theory is that it can make businesses focus on short term profit maximization. If firms do not engage in CSR programs then they will not be able to reap the long term 
dividends that can be achieved from such social actions.

- Some people claim that the shareholder theory do not encourage businesses to treat all stakeholders in a fair and equal manner. If companies only focus on shareholder profit maximization then other stakeholders like customers and employees may get disgruntled.

\section{Conclusion}

In the past, concept of CSR has been questioned by many business leaders but today CSR has become the central focus of a modern corporation. According to Lee (2008), CSR has been transformed from an irrelevant and frowned upon idea to one of the most widely accepted concepts in the business world. Today most of the businesses are implementing CSR policies because the corporate executives believe that this will eventually yield long term benefits. Some executives think that CSR can give them a competitive edge over their rivals in the market, leading to greater market share. Firms also believe that by engaging in CSR activities they can win customer loyalty and goodwill. Firms can also use CSR as a competitive strategy to force the weak firms out of the industry. Moreover, the economic value of CSR has increased as the beliefs of employees, consumers and shareholders have changed over the years. Consumers are now demanding more than a product from their favorite brands. Employees are choosing to work for companies with strong values. Shareholders are more inclined to invest in businesses with outstanding corporate reputation. Firms that fail to conduct CSR may have to face consequences in the form of loss of sales, negative publicity and a discontented workforce which could eventually lead to a decline in future shareholder wealth.

Nevertheless, some critics of CSR point out that if firms invest their money in CSR projects but do not get proper return from such investments then these firms will be failing their obligations to the shareholders. These researchers argue that firms should only engage in socially responsible actions if such projects give profitable returns and competitive advantage in the long run. Wallace (2003), emphasized that the return from CSR should be evaluated. He states "as with any corporate investment, each dollar of investment in a corporate action should be justified by at least a dollar of expected return over a finite time horizon".

To what extent a firm will engage in CSR activities can vary depending on the norms of a particular industry and external pressures from government. In some industries CSR may not be necessary whereas in other industries CSR may be the norm. Before firms undertake any CSR programs they must thoroughly analyze the effects of such programs on the various stakeholders. Moreover, firms should try to get feedback concerning the effectiveness of their CSR practices to uncover areas of further improvements and where they are doing well (Walton, 2010).

Lastly, in this paper we have highlighted some important CSR concepts and theories to understand why or why not companies should act in a socially responsible way. Exploring the various theoretically oriented researches on this subject, we have learned that although a firm's main objective is to maximize the wealth of its shareholders but it should not try to pursue this goal at the expense of its other stakeholders. In order to make profits, firms should not deliberately harm the interest of other stakeholders because in the long run they will have to bear negative consequences. Similarly, firms that believe in performing activities which will resolve social problems should not go out of their way to promote social welfare at the expense of shareholders' wealth. Hence, decisions by firms regarding CSR should be based on balancing the needs of all the parties. Businesses should pursue CSR activities to provide benefits to the community as well as to enhance the long term wealth of its shareholders.

\section{References}

Basu K., \& Palazzo, G. (2008). Corporate social responsibility: A process model of sense making. Academy of Management Review, 33, 122-136.

Bowen, H. R. (1953). Social responsibilities of the businessman. New York: Harper \& Row.

Carroll, A. B. (1979). A three-dimensional conceptual model of corporate social performance. Academy of Management Review, 4, 497-505.

Davis, K. (1960). Can business afford to ignore social responsibilities? California Management Review, 2, 70-76.

Davis, K., \& Robert, L. Blomstrom. (1971). Business, Society, and Environment: Social Power and Social Response (2nd ed.). New York: McGraw-Hill.

Davis, K. (1973). The case for and against business assumption of social responsibilities. Academy of Management Journal, 16(2), 312-322. Retrieved from http://journals.aomonline.org/amj/

Frederick, W. C. (2006). Corporation, be good! : The story of corporate social responsibility. Indianapolis, IN: Dog Ear Publishing.

Freeman, R. E., \& Liedtka, J. (1991). Corporate social responsibility: A critical approach. Business Horizons, 34(4), 92-98. Retrieved from http://www.elsevier.com/inca/publications/store/6/2/0/2/1/4/

Freeman, R. E., Wicks, A. C., \& Parmar, B. (2004). Stakeholder theory and the corporate objective revisited. Organization Science, 15(3), 364-369. Retrieved from http://orgsci.journal.informs.org/

Friedman, M. (1970, September 13). The social responsibility of business is to increase its profits. New York Times 
Magazine, 1-6.

Friedman, M. (1971). “Does business have a social responsibility?", Bank Administration, pp. 13-14.

Friedman, M. (2002). The social responsibility of business is to increase its profits. In L. P. Hartman (Ed.), Perspectives in business ethics (2 ${ }^{\text {nd }}$ ed.) (pp. 260-264). New York: The McGraw Hill Companies.

Guthrie, J., \& Parker, L. D. (1989). Corporate social reporting: A rebuttal of legitimacy theory. Accounting \& Business Research, 19(76), 343-352. Retrieved from http://www.abr-journal.com/

Heald, M. (1970). The social responsibilities of business: Company and community. Cleveland, OH: Case Western Reserve University Press.

Jensen, M. C. (2002, April). Value maximization, stakeholder theory, and the corporate objective function. Business Ethics Quarterly, 12(2), 235-256. Retrieved from https://secure.pdenet.org/pdc/pvdb.nsf/journal?openform\&journal=pdc\%5Fbeq

Johnson, H. L. (1971). Business in contemporary society: Framework and issues. Belmont, CA: Wadsworth.

Lee, M. P. (2008). A review of the theories of corporate social responsibility: Its evolutionary path and the road ahead. International Journal of Management Reviews, 10(1), 53-73. Doi:10.1111/j.1468-2370.2007.00226.x

Manne, H. G., \& Wallich, H. C. (1972). The Modern Corporation and social responsibility. Washington, DC: American Enterprise Institute for Public Policy Research.

McGuire, J. W. (1963). Business and Society. New York: McGraw- Hill.

Samuelson, P. A. (1971, Spring). Love that Corporation. Mountain Bell Magazine.

Sethi, S. P. (1975). Dimensions of corporate social performance: An analytic framework. California Management Review, 17, 58-64.

Smith, A. (1981). An inquiry into the nature and causes of the wealth of nations. Indianapolis, IN: Liberty Classics.

Smith, N. C. (2002). Arguments for and against corporate social responsibility. In L. P. Hartman (Ed.), Perspectives in business ethics, (pp.231-236). New York: The McGraw Hill Companies.

Wallace, J. (2003). Value Maximization and Stakeholder Theory: Compatible or Not? Journal of Applied Corporate Finance, 15 (3), 120-127.

Wallich, H. C., \& McGowan, J. Stockholder interest and the corporation's role in social policy. In W. J. Baumol et al. (1970). A New Rationale for Corporate Social Policy (pp. 39-59). New York: Committee for Economic Development.

Walton, C. C. (1967). Corporate social responsibilities. Belmont, CA: Wadsworth.

Walton, S. B. (2010). Do the right thing: measuring the effectiveness of corporate social responsibility. Public Relations Tactics, 17(7), 10-11. Retrieved from http://www.prsa.org/tactics.html 